\title{
Asian Zakat Management Organization (ZMO) Productivity Analysis: Evidence in Indonesia
}

\author{
Tika Widiastuti ${ }^{1 *}$, Anidah Robani ${ }^{2}$, Muhamad Nafik Hadi Ryandono ${ }^{1}$, A. Syifaul \\ Qulub $^{1}$, Eko Fajar Cahyono ${ }^{1}$, Nova Rini ${ }^{3}$, Safika Rosyidatul Arifah ${ }^{1}$ and \\ Taqiyah Dinda Insani ${ }^{1}$
}

\author{
${ }^{1}$ Faculty of Economy and Business, Universitas Airlangga, Surabaya, East Java, Indonesia \\ ${ }^{2}$ lecturer of University Teknikal Malaysia Melaka, Malaysia \\ ${ }^{3}$ lecturer of STIE Muhammadiyah, Jakarta, Indonesia \\ *Corresponding author email: tika.widiastuti@feb.unair.ac.id
}

\begin{abstract}
The Covid-19 pandemic made several countries in the asian world especially Indonesia is a decline in various aspects, especially the economic aspect, namely poverty. whereas in economic instruments there is a solution to overcome it, namely by means of zakat. But unfortunately zakat management in Indonesia has not been maximally productive. In fact, if zakat institutions implement productivity optimally, it will be able to increase community empowerment and maintain the country's economy. Therefore, this research was conducted to analyse productivity level of Zakat Management Organization (ZMO) in Indonesia based on its organization types, namely government, civil social organizations, and corporations. The level of productivity is measured based on the method of Malmquist Productivity Index (MPI) on 14 ZMO in Indonesia. This study reveals that ZMO managed the order of productivity by government, civil social organization, and corporation. The theory of specific productivity for developing ZMO performance, and provides the information of productivity level of ZMO and the information of the collected zakat funds and their distributions. The limitation of this study is the analysis period of productivity level and the range of zakat institutions as the object of the study.
\end{abstract}

Keywords: Asian, Indonesia, Productivity, ZMO

\section{INTRODUCTION}

Indonesia has experienced an increase in poverty, especially in the midst of the Covid-19 pandemic. There are several countries in the world claimed to have the highest number of Covid-19 cases, and Indonesia is ranked as the ninth in Asia (Databoks, 2020) Hence, it has a significant impact on some economic sectors of the country. The poverty rate in Indonesia in the first quarter of 2020 increased by 0.56 percent, compared to the previous quarter (BPS, 2019), supported by the evidences such as from the tourism sector which the trade has decreased (Nasution, D. A. D., Erlina, 2020). An increase in the number of layoffs is seen (Meilianna, N. R., \& Purba, 2020) and many children are threatened to be dropped out of school because of their inadequate facilities to support (Aji, 2020). Therefore, a strategy is needed to reduce this poverty.

Zakat is one of the Islamic financial instruments that functions to reduce poverty, especially since Indonesia is a country that have the largest Muslim community in the world (Databoks., 2019) and all Muslims are obliged to give zakat. Therefore, zakat management is needed optimally to reduce the level of poverty in Indonesia (Huda, N., Anggraini, D.,
Ali, K. M., Mardoni, Y., \& Rini, 2014) The Zakat Management Organization (ZMO) is a public organization that has the goal of prospering the physical and spiritual needs of the community through the collection, management and distribution of zakat funds, collected from the community and to be given to the community (Fadilah, S., Lesatari, R., \& Rosdiana, 2017). Asian countries with a majority of Muslim population such as Malaysia with 63.7 percent of Muslim population, Saudi Arabia with 93 percent of Muslim population, Brunei Darussalam with 75 percent of Muslim population, and Pakistan with 96.4 percent of Muslim population (Facts., 2020) have a centralized zakat management system (Nadhari, 2013). Meanwhile, Indonesia with 87.2 percent of the Muslim population (Religion Facts, 2020) does not use a centralized zakat system.

In Malaysia, the zakat management system is categorized into three types, namely corporate, semi-corporate, and government systems. However zakat institutions in Malaysia are only assigned to manage and collect zakat, while the distribution process is handled directly by the state government (Nadhari, 2013). Not only that, the Malaysian government has responsibility to ensure that 
Muslims in Malaysia have paid zakat, because it is a measure of community compliance with Islamic law (Abdullah,. \& Sapiei, 2018). Meanwhile, in Saudi Arabia, the authority to collect zakat is in the hands of the Minister of Finance and National Economy, and the authority to distribute zakat is in the hands of the Minister of Social Affairs (Nadhari, 2013) Similar to Saudi Arabia, in Brunei Darussalam the management of zakat is directly handled under the authority of the Islamic Ugama Council (Jaelani, 2015) Likewise in Pakistan, zakat management is directly centralized or under the control of Central Zakat Fund (CZF) which was formed by the government (Nadhari, 2013)

Institutionally, there are several types of organization in ZMO grouping, such as zakat management by the government and corporations, the government and the private corporates (Nadhari, A.K., 2013; Nuraisyah, et.al. 2019). This study pursued to accommodate the ZMO grouping according to the existed grouping. The ZMO grouping is divided into three types, namely: 1) Government; 2) Civil Social Organization; 3) Corporation.

According to the data from last year, zakat funds collected in Indonesia compared to the poverty rate in 2019 was only around Rp. 3.9 trillion from the total potential of 233.84 trillion (BAZNAS., 2019), while on the other hand the poverty line was recorded at 425.250, - / capita / month with total population of poor 24.79 million people (BPS, 2019). It means that the zakat collected is only able to reduce poverty by 38 percent. The condition would be different if the potential for zakat can be optimally collected, it will be able to reduce the poverty rate even more, by 227.6 percent or equal to 22 times the needs of the poor per individual. This condition shows that the role of zakat management organizations as institutions for collecting zakat funds is still not developed optimally and unfortunately the fund collected is still far from its potential. Therefore, ZMO must develop its productivity. Productivity is the ability of zakat institutions in managing zakat that is accountable and has an impact on improving social welfare (Wahab, N. Abd., \& Rahman, 2012). Measurement of ZMO productivity is generally carried out using production approach, which means the collected zakat and distributed zakat is part of the ZMO output (Piliyanti, I., \& Meilani, 2020)

This article discusses the productivity of ZMO which is classified through zakat management grouping. Zakat Management Organization (ZMO) in this study is divided into three types, categorized by ZMO government, ZMO civil social organization, and ZMO corporations. This becomes a unique point of the study, because there has not previous research that measured the productivity of ZMO classified through zakat management group. Measurement of productivity using MPI assumes that the data is complete for each ZMO and for every year. The latest data that ZMO published on their official website averagely is up to the period of 2018. Meanwhile, complete data is available from the period of 2016. Therefore, this study uses data from the period of 2016-2018.

Previous researchers have analysed in various entities, the first one is in business entities such as corporations (Nurasyiah, A., Adam, F., \& Pertiwi, 2019) The second is in financial entities (Rustyani, S., \& Rosyidi, 2019) and the third is in non-business institutions (Wahab, N. Abd., \& Rahman, 2013) Previous researchers have also found several zakat issues such as evaluating the productivity of zakat institutions in Indonesia (Rustyani, S., \& Rosyidi, 2019)evaluating the productivity of zakat institutions in Malaysia (Wahab, N. Abd., \& Rahman, 2012) and measuring the productivity of District ZMO (Government Amil) in the West Java region in the period of 2012-2016 (Firmansyah, et.al, 2020), as well as evaluation of campus-based organization of Amil Zakat institutions (UGM, UNS, and UNISULA) in the period of 2015-2016 (Piliyanti, I., \& Meilani, 2020). Some researchers also apply productivity banking, for example, by a change in TFP value which is carried out by (Yaumidin, 2007), (Raphael, 2013), and (Yildirim, 2015). (Yaumidin, 2007) in his research compares the level of efficiency of Islamic banks in the Middle East and Southeast Asia coming from banking failure cases which then had an impact on the crisis, both domestically and internationally, showing that Islamic banks in Southeast Asia were slightly more efficient than Islamic banks in the Middle East. One of the causes is the 9/11 tragedy in 2001 and the Iraq war in 2002, likewise the change of TFP value. Furthermore, research that applies efficiency and productivity measurements to zakat institutions in Indonesia using Data Envelopment Analysis (DEA) and Malmquist Productivity Index is conducted by (Parisi, 2017), (Rustyani, S., \& Rosyidi, 2019) However, there are not many studies that analyse the productivity of zakat organization based its management group such as government, corporations and civil social organizations in recent periods. Therefore, this fact became the basis of the study which then the 
purpose is to find the productivity level of $\mathrm{ZMO}$ based on its type of organization in the period years of 2016-2018.

This article uses data of financial statements from 14 Zakat Management Organizations (ZMO) in the period of 2016-2018. The method used is Malmquist Productivity Index (MPI). The Malmquist Productivity Index (MPI) is a method prior developed by Caves, Christensen, and Diewert in 1982 as an approach that functions distance to compare production technology in defining the index of input, output, and productivity (Rustyani, S., \& Rosyidi, 2019). This research contributes in providing information on the productivity of zakat institutions in terms of costs management and adjustment to era development, as well as knowledge about collecting process and distribution of zakat funds. This information will be used as written matter for the government and the authorities to improve ZMO management, particularly to increase the productivity of zakat organizations.

The composition of this article consists of (1) introduction, (2) literature review, (3) methodology, (4) results of study and discussions, (5) conclusions, and (6) bibliography. (1) Introduction contains background, research gaps and phenomena. (2) Literature review contains the theories and previous researches that support this study. (3) Methodology contains the methods used to measure the level of productivity. (4) Results of the study and discussions contain the results of data calculations and analysis of the comparison between the results of this study and previous theories and researches. (5) Conclusion contains the answer of the problem statement. (6) Bibliography contains references used in this study.

\section{LITERATURE REVIEW \\ 2.1 Zakat in Economic Prespective}

Zakat means cleansing or purifying, growing and developing (Ministry of Religion of the Republic of Indonesia 2013). From the viewpoint of fiqh, zakat is a certain amount of assets which are obliged by Allah to be submitted to the person who entitled to receive it. Zakat is a combination of growing and purifying (Kahlani in (Bahri, 2016)). Ibn Taymiyyah once said that zakat cleanses everything, as well as the wealth will be cleaned and its value will be multiplied (Madania, Citra., Muhammad, 2016). Alquran mentions zakat thirty times, twenty seven of which are the obligation to offer prayers accompanied by paying zakat. Zakat is also part of social obligations and zakat is very dependent on sharia compliance and the financial capacity of each individual in the community (Abbas, 2020).

Zakat is worship of maaliyah ijtima'iyyah which means that zakat is the most important and strategic worship both in terms of Islamic discipline and the welfare development of the community (Religion, 2013) Zakat is proven to have a role in improving the welfare of the community and overcoming poverty that occurs in society, such as during the postRasulullah SAW supremacy, the welfare of the people was evenly allocated, due to the success of the government in managing zakat, infaq and sadaqa funds (Bahri, 2016). Zakat distribution must uphold the principles of social justice and redistribution because zakat is the solution aiming at equal distribution of income (Nasution, \& Muhammad, 2019). In the distribution of collected zakat funds, it must be distributed to the formation entitled to receive zakat (Mustahiq). This formation is commonly known to be formed by the eight ashnaf 1) fakir (those who cannot reach the economic rank to make the ends meet); 2) poor (those who cannot make ends meet); 3) amil zakat (those who in charge of managing zakat); 4) mu'allaf (people who recently include in Islamic belief); 5) liberating the riqab (slave); 6) liberating gharim (those who are in debt); 7) sabilillah (those who strive in Allah's path); 8) ibn sabil (those who run out of supply on the way of a physical journey). (Surah At-Taubah verse 60).

The main purpose of zakat distribution is to eliminate poverty and destitution. In addition to these main objectives, other purposes of zakat distribution include (Djuanda, 2006):

- Solutions to life's difficulties

- Mitigating economic inequality

- Developing an attitude of social responsibility and discipline.

- Instrument of social justice

The benefits of zakat distribution for muzakki include 1) purifying the soul from stingyness, 2) as an education on the attitude of giving and infaq, and 3) as a manifestation of gratitude for Allah's blessings. While the benefits of zakat for mustahiq (zakat recipients) include 1) accomodate them meet the needs of life and 2) remove hatred and envy towards rich people who become hunks. Then, the benefits of zakat for the community are that zakat has economic value, which is able to realize the function of material property as a mean of struggle to uphold the religion of Allah (jihad fii sabilillah), and realizing the socio-economic justice of society, as stated in the following verse: Take, [O Muhammad], from their wealth a charity by which you purify them and cause them increase, and invoke 
[Allāh's blessings] upon them. Indeed, your invocations are reassurance for them. And Allāh is Hearing and Knowing (Surah At-Taubah: 103).

Further, (Wahbah, 1984) describes the purpose of zakat for the benefit of society, such as:

- Raising the enthusiasm and courage of mutual support and social solidarity among the community of Muslim.

- Close the gap and adjoin the distance of socioeconomic disparities in the community.

- Overcoming financial difficulties arising from various obstacles such as natural disasters and so on.

- Cover the costs arising from conflicts, disputes and various forms of chaos in the community.

- Providing tactical and specific funds for the overcoming living costs of the homeless, unemployed, and other social disabled, including the funds to help people who have the intention of getting married but do not have the funds for it.

\subsection{Zakat Management Organization (ZMO) Performances.}

Zakat Management Organization (ZMO), also known as amil zakat, play crucial role in zakat distribution. If amil zakat is managed properly, zakat can have the actual significant positive effect on mustahik. However, if the amil zakat is managed less than its highest potential, it can be assumed that the mustahik rights will not be fulfilled. Those become the determiner of the essential value of amil zakat (Parisi, 2017) In other words, the most vital thing about zakat is the management of zakat funds so that the organizations can reach optimal productivity (Parisi, 2017) The performance of zakat management organizations plays a prominent role in earning public trust to pay zakat through zakat management institutions. A productive ZMO will attract more people in the community to carry out the obligation of paying zakat (Wahab, N. Abd., \& Rahman, 2012).

Knowing the complexity of ZMO responsibilities, ZMO performance can be measured by various measurements, such as the National Zakat Index (IZN), Suburb Zakat Index (IDZ), International Standard of Zakat Management, etc. This measurement is accounted by an appropriate zakat audit report according to PSAK No. 109. Thus, ZMO performance can be measured properly (Beik, 2009). Not only that, Kahf (1989) has also stated in (Ahmad, 2014) that Rosulullah SAW once said zakat will optimally achieve the goal of poverty eradication, if $\mathrm{ZMO}$ is able to coordinate the management and distribution productively. The growing productivity of ZMO will make people more actively paying zakat (Kahf, 1989 ; (Ahmad, 2014) Thus, the distribution of zakat funds to mustahiq can be ideally advantageous, and the poverty rate decreases. The Indonesian Minister of Finance at the 2nd Annual Islamic Finance Conference (AIFC) 2017 uttered that the role of ZISWAF would greatly help the government economy (Keuangan., 2017) Hence, the main point of the success achieved by zakat management organization lies in the accountability of reporting its management and distribution process. In result, the donors of each ZMO will routinely give zakat through the institution. Islam also teaches the concept of tawazun, which Muslims, as social beings, are encouraged to balance themselves according to era development and be accountable for their actions (Maali., Et.al. 2006 ; (Sartawi, 2020). Therefore, it is important to manage zakat organization rightly.

\subsection{ZMO Role as a Policy Management.}

Management is an art and a science that is utilized to achieve goals. Arnoldo C Hax and Nicolas in their book 'strategic management' defined that management is needed for organizational development, giving the organization guidance to achieve organizational goals (Nugraha, 2018). Management is an important element of an organization because the success of management will support the success of more advanced innovation, because good organizational management may breed new strategic findings during organization development (Khamis, N., Sulaiman, A., \& Mohezar, 2014). Policy management is not about the process or making decision, but related to the formation, maintenance and implementation of an organization's policies. This is because the goal of policy management is to control the organization. What is lacking in policy management among the community is that the use of technology as an adaptation in an organization or company is overestimated, because it is undeniable that technology can provide answer to almost all the existing problems nowadays. Therefore an organization should not be separated from policy management (Maullo, M.J., \& Calo, S.B., 1993).

There are several aspects that cannot be separated in policy management, namely, 1) Planning (arranging and examining organizational plans), 2) Organizing (establishing the form of organization to achieve goals), 3) Actuating (providing driving force for organizational performance), 4) Controlling (supervision and evaluation) (Yacoeb, 2013). Islam recommends that 
people behave adequately and fairly in their affairs, as stated in the verse: "Indeed, Allah orders justice and good conduct and giving to relatives and forbids immorality and bad conduct and opinion. He admonishes you that perhaps you will be reminded" (QS. An-Nahl: 90). There are also several management policies regarding the strategy of a organization or company based on sharia, such as: 1) the company should create more conservative policy, 2) staying away from projects that have excessive risk or uncertainty (gharar), 3) the company should revise the company's leverage level to meet its financial criteria, 4) improving and fostering sharia compliance of the company's employees and resources, (Khaw, 2019) So, the benefit of implementing policy management in ZMO is that employees will put more loyalty and totality in managing zakat. Organizational commitment is a strategy that must be carried out by $\mathrm{ZMO}$ is because it has major implications for the employees and the sustainability of the organization itself (Lo, M., Ramayah, T., \& Min, 2009)

In the management policy of an organization, it is necessary to make the community take interest in the organization. For example, in a zakat organization it is important to create innovation to encourage investors / zakat donors to concern, and then provide funds in a sustainable manner (Muhamad, R., Melewar, T. C., \& Alwi, 2011). All organizations need to improve organizational accountability, as well as zakat organizations, because the awareness of organizational accountability in various developed countries is needed for risk management and controlling organization (Sarrens, G., \& Christopher, 2010) However, the needs of controlling organization are also influenced by the environment of the organization itself. Hence, the character and the loyalty of employee, as well as organizational culture will influence the management policy of ZMO (Parker, 1984)

\subsection{Concept and Evaluation of Productivity}

Productivity is how to produce or achieve the highest possible results of goods and services by utilizing human resources efficiently, while it is also often interpreted as the ratio between output and input in certain units (Rustyani, S., \& Rosyidi, 2019). If it is implemented in terms of zakat institutions, productivity is interpreted as how to increase collected zakat funds and distribute in order to achieve the maximum result. Productivity can be measured partially or wholly. An increase in the productivity ratio means that higher output is produced using smaller number of inputs (Avenzora, 2008). Partial measurement calculates the relationship between output and one input, while total measurement means calculating the relationship between output and input.

Productivity is an instrument that is ideally concerned by a company or organization. In addition, to increase the quality of the organization, it requires a development of the level of productivity of the organization (Nurprihatin, 2017) There are three important things that must be known in productivity measurement, as follows: First, the measurement of productivity will have an impact on the process of the end product; second, productivity measurement will have an impact on the profitability of organization or company; third, productivity measurement will have an impact on changing one of the variables (Deoranto, 2016)Productivity is the capability of zakat institutions in managing the affairs of zakat towards the purpose of increasing social welfare and accountability to zakat donors (Wahab, N. Abd., \& Rahman, 2012) Also, the virtue of productivity is explained in the Qur'an as in the following verse: "And We have certainly honored the children of Adam and carried them on the land and sea and provided for them of the good things and preferred them over much of what We have created, with [definite] preference "(Surah AL Isra 'verse 70). Thus, it can be concluded that productivity is the main key for organization, including $\mathrm{ZMO}$, to achieve their goals because productivity is an essential part in the progress of organization (Enhassi, 2007).

\subsection{Malmquist Productivity Index (MPI).}

Malmquist Productivity Index (MPI) is an approach of distance function to describe technology on defining indices of input, output, and productivity. The Malmquist Productivity Index (MPI) is able to depict the level of productivity into technical and technological efficiency. On the MPI criteria, if the value of the Malmquist index is less than 1 then there is a decrease in productivity, and if the index is more than 1 , meaning there is an increase in productivity. Meanwhile, if it is equal to 1 then there is no change in performance. MPI on production refers to the ratio of the two output distance functions which represent the multi-input and production technology. Multi output without the participation of explicit data price is a requirement in describing the behaviour assumptions of profit maximization or cost minimization. MPI measures changes in productivity in terms of input and output in the profitable production process ((Akpan, M. N. U., \& Akpan, 2019) Ihaddaden, 2020; (Nurasyiah, A., 
Adam, F., \& Pertiwi, 2019); (Obi, O. F., \& Visser, 2020) ; (Pathak, 2019); (Tzeremes, 2020)

The Malmquist Index has several favourable characteristics. First, this index is a non-parametric method so that it does not require a specific production function form. Secondly, the Malmquist index does not require assumptions about the economic behaviour of the production unit such as cost minimization or profit maximization, so it is useful enough if the goals of producers are different or unknown. Third, the calculation of this index does not require data price that is often unavailable. Fourth, the Malmquist productivity index can be broken down into two components, namely changes in efficiency and changes in technology (Djaghballou, C.-E., Djaghballou, M., Larbani, M., \& Mohamad, 2018) In addition to efficiency shifting, a shift in technology of population will affect the regression and progress of a unit from one period into the next one (Negar, et, 2017)

\section{METHOD}

The approach utilized to answer the statement of problem is quantitative approach by the Malmquist Productivity Index (MPI) method through DEAP 2.1 which specifically notice the level of productivity of a business unit, and in this study is ZMO, based on input and output that can be analyzed. This study estimate TFP growth and its components referring to the Malmquist Index and uses the Cobb-Douglas production function. The Cobb-Douglas production function is written as follows:

$$
Y=A * L^{a} * K^{(1-a)}{ }^{(1)}
$$

The equation expressed measurement of the total factor productivity, which scale A has economic value. The geometric weighted average of the input is used to produce the real output. Thus, A can be interpreted as real output per unit of input. This is a measure of productivity that is better than Y/L and $\mathrm{Y} / \mathrm{K}$ which measures productivity partially and do not take the possibility of other input numbers into account (Rusydiana, 2018).

Total Factor Productivity (TFP) itself has the meaning of simultaneously measuring the relationship between input and output, this relationship is expressed in the ratio that comes from the output index to the aggregate input. If the ratio increases, it means that more output will be produced, or in other words, more number of outputs can be produced using fewer inputs. TFP is measured using index numbers that calculate changes in price and quantity over time. In addition, TFP also measures the comparison and differences between entities. Indices that are often used to measure TFP are the Malmquist Index, Laspeyres Index, Pasche Index, Fisher Index and Tornqvist Index. In this study, the index which will be used to calculate the level of productivity (TFP) is the Malmquist Index ((Avenzora, 2008) ; (Parisi, 2017)).

From the description above, this study conducted research using 14 samples of Zakat Management Organizations (ZMO) in Indonesia in the period of 2016-2018. The process of selecting is based on purposive sampling technique: zakat institutions that uploaded financial reports on their respective official websites during 2016-2018. The selected ZMOs are: (1) National Zakat Agency (BAZNAS), (2) Baitul Maal Muamalat (BMM) ), (3) Bank Syariah Mandiri Amil Zakat Institution (BSM), (4) Global Zakat, (5) Al-Azhar Amil Zakat Institution (LAZ AL-Azhar), (6) Dompet Dhuafa Republika (DDR), (7) Indonesian Zakat Initiative (IZI), (8) Mizan Amanah Zakat Institution (Mizan), (9) Rumah Zakat (RZ), (10) Dompet Dhuafa (DD), (11) Amil Zakat Institution Infaq Shodaqoh Nahdlatul Ulama (LAZIS NU) , (12) Majelis Ta'lim Telkomsel (MTT), (13) Madani Welfare Foundation (Yakesma), (14) and Baitul Maal Foundation for the State Electricity Company (YBM PLN). Input variables used include variable socialization expense, variable salary expense, and variable operating expense. Meanwhile, the output variables used are distributed zakat and zakat fund. The analysis tool used in this study is DEAP 2.1 software.

\section{RESULT AND DISCUSSION}

Measuring the performance of the Zakat Management Organization (ZMO) usually requires several variables that cannot be separated from ZMO activities such as how much funds have been collected by ZMO and how the funds distributed. Below is the overview of ZMO's operational activities in Indonesia using several input and output variables that exist in each ZMO. These variables are used to measure the $\mathrm{ZMO}$ productivity score in Indonesia during the period years of 20162018 and described in Table 1 as follows: 
TABLE 1. Descriptive Statistics of Input and Output Variables of Zakat Management Organization (ZMO) in 2016-2018 (in Rupiah)

\begin{tabular}{|c|c|c|c|}
\hline Variable & Average & Maximum & Minimum \\
\hline \multicolumn{4}{|l|}{ Input: } \\
\hline $\begin{array}{l}\text { Variable Socialization } \\
\text { Expense }\end{array}$ & $3,825,212,334$ & $23,367,138,542$ & $5,121,923$ \\
\hline $\begin{array}{l}\text { Variable Salary } \\
\text { Expanse }\end{array}$ & $7,624,019,383$ & $51,895,788,070$ & $11,604,300$ \\
\hline $\begin{array}{l}\text { Variable Operating } \\
\text { Expanse }\end{array}$ & $10,677,305,242$ & $70,001,294,079$ & $12,804,807$ \\
\hline \multicolumn{4}{|l|}{ Output: } \\
\hline Zakat Distributed & $62,365,159,114$ & $288,670,038,833$ & $2,338,004,030$ \\
\hline Zakat Collected & $62,686,113,219$ & $229,788,106,390$ & $2.594,266,277$ \\
\hline
\end{tabular}

Source: Output Software DEAP 2.1. Compiled by Authors (2020)

Table 1 shows the three input variables and the two output variables in this study. The variable socialization expense is spread between IDR 5.1 million and IDR 23.4 billion with 14 ZMO having a nominal value above average of 3.8 billion. Second, variable salary expense is spread between IDR 11.6 million and IDR 51.8 billion, with 14 ZMO having a nominal value below the average of 7.6 billion. Third, the variable operating expansion is spread between IDR 12.8 million and IDR 70 billion with $14 \mathrm{ZMO}$ having a nominal value below the average of 10 billion. Then, zakat fund has a nominal value of 62.3 billion, which means that zakat organizations in terms of collecting zakat have been able to reach above average. In addition, zakat distributed spread between IDR 2.3 billion and IDR 288.6 billion, where the nominal value is 62.6 billion, meaning that the organizations have been able to distribute zakat above the average value.

ZMO productivity can be seen from the Total Factor Productivity Change. In table 2, the total factor of change in productivity is examined through the value of the Efficiency change Index (EFFCH) and the Technology Change Index (TECH), explaining the reasons for changes in productivity.
$\mathrm{EFFCH}$ is an indicator that describes the company's ability to maximize the output produced. Meanwhile, TECH is an indicator that describes the use of technology and innovation by the company. Then TFPCH is the final value that determines the decrease or increase in productivity (Fukuyama, 1995). Table 2 describes the results of the estimated value of the Malmquist Productivity Index (MPI) from ZMO in Indonesia which are included in the observation.

(Nurasyiah, A., Adam, F., \& Pertiwi, 2019) stated that the existence of BAZNAS and LAZ as $\mathrm{ZMO}$ in Indonesia does not make these two amil zakat compete for obtaining muzakki. The competition that occurs is more likely as part of fastabiqul khoirot (competing in kindness virtue) by inviting people in fulfilment of the third pillar of Islam, zakat obligation. Therefore, this study analysed by measuring the level of productivity in each ZMO according to its categories in Indonesia, namely the categories of government, civil social organization, and corporation, during the period of 2016 - 2018. The results of the calculations can be seen in the following table:

TABLE 2. Malmquist Index Summary based on the ZMO

\begin{tabular}{|c|l|l|c|c|c|c|}
\hline No. & $\begin{array}{c}\text { Organization } \\
\text { Type }\end{array}$ & ZMO & EFFCH & TECH & TFPCH & Rank \\
\hline 1 & Government & BAZNAS & 0.845 & 2.223 & 1.879 & 2 \\
\hline \multicolumn{2}{|c|}{ Average } & $\begin{array}{l}\text { Global } \\
\text { Zakat }\end{array}$ & 1.000 & 2.034 & 2.034 & 1 \\
\cline { 4 - 7 } & Organil Social \\
\cline { 3 - 7 } & & Yakesma & 1.000 & 1.337 & 1.337 & 4 \\
\cline { 3 - 7 } & RZ & 0.894 & 1.492 & 1.333 & 5 \\
\hline
\end{tabular}




\begin{tabular}{|c|c|c|c|c|c|c|}
\hline 5 & & $\mathrm{NU}$ & 1.168 & 1.032 & 1.205 & 6 \\
\hline 6 & & DDR & 1.038 & 1.158 & 1.202 & 7 \\
\hline 7 & & IZI & 0.859 & 0.937 & 0.805 & 9 \\
\hline 8 & & Mizan & 0.747 & 1.006 & 0.751 & 10 \\
\hline 9 & & Al-Azhar & 0.791 & 0.884 & 0.700 & 11 \\
\hline 10 & & $\mathrm{DD}$ & 0.789 & 0.866 & 0.683 & 12 \\
\hline \multicolumn{3}{|c|}{ Average } & 0.921 & 1.194 & 1.117 & 2 \\
\hline 11 & \multirow[t]{4}{*}{ Corporation } & YBM PLN & 1.024 & 1.740 & 1.783 & 3 \\
\hline 12 & & $\mathrm{BMM}$ & 1.000 & 1.036 & 1.036 & 8 \\
\hline 13 & & MTT & 0.572 & 1.140 & 0.652 & 13 \\
\hline 14 & & BSM & 0.944 & 0.615 & 0.580 & 14 \\
\hline \multicolumn{3}{|c|}{ Average } & 0.885 & 1.133 & 1.013 & 3 \\
\hline \multicolumn{3}{|c|}{ Total Average } & 0.898 & 1.120 & 1.005 & - \\
\hline \multicolumn{7}{|c|}{$\begin{array}{l}\text { EFFCH : The ability to maximize output value with same value of input } \\
\text { TECH : Changes in management ability to run the operations to increase efficiency } \\
\text { TFPCH : Total change of factor productivity (Total EFFCH x TECH = Productivity } \\
\text { Level) }\end{array}$} \\
\hline
\end{tabular}

Source: Output Software DEAP 2.1.

Compiled by Authors (2020)

The conclusion of the data showed table 2 is the zakat institution managed by government category ranks the highest among other categories with an average of 1.879 in productivity level (TFPCH). This is because the characteristics of ZMO included in government type where the organization themselves have been given tremendous support and attention from government in developing the potential for zakat in Indonesia. Therefore, it is not surprising that the contribution of BAZNAS's productivity value of 2.223 is mostly obtained from the value of technological innovation (TECH). However, by looking at level of cost efficiency $(\mathrm{EFFCH}), \mathrm{BAZNAS}$ received low score of $<1$ or 0.845 . This happens because BAZNAS is the only zakat institution that accommodates the government as zakat distribution reference and its main responsibility is to compile, to study and to analyze the performance of zakat institutions in Indonesia making sure that they are in compliance with the rules of zakat institutions (BAZNAS., 2019). This is supported by Wahyuni's research in 2016 which stated BAZNAS has not been able to optimize the collection and distribution of zakat according to its financial statement in 2018 and 2019, where the nominal of collection and distribution was still lower compared to other zakat institutions (BAZNAS., 2019). That is reason why the efficiency value of BAZNAS is considered low. It is different from Malaysia's rule, where all zakat activities are supervised by the State Islamic Religious Councils (SIRC) while the regulators and executioners are delegated to the respective states, so that the level of efficiency is managed directly by each state (Wahab, N. Abd., \& Rahman, 2013)

Zakat institutions include in the category of civil social organizations are in second place with the level of productivity (TFPCH) of 1,117 . This acquisition is obtained from the efficiency value $(\mathrm{EFFCH})$ of 0.921 which is higher than the efficiency value of the government category. This is due to the fact that civil social organizations are more self-sufficient in issuing and monitoring the costs of fulfillment such as operational facilities etc. However, ZMO in this category of civil social organization still need to increase their efficiency because the minimum efficiency rate of $=1$ has not achieved yet. In case of the technological innovation (TECH), civil social organizations' value is lower sthan the governmental type, which is 1.194 . This may be due to the costs for innovation budget purposed to technological innovation is considered 
grand, and not all zakat institutions are able to maintain it. Therefore, zakat institutions under the group of civil social organizations must develop technological innovation that is rapidly evolved, because advances in technology and information have changed the way data measured and information published to the society (Isa, C. R., Foong, S. Y., \& Sambasivan, 2005) In order to maintain muzakki's trust in the organizations, it is necessary for the organization to adapting the era development. This era of globalization, where technology is developing rapidly in the community, demands financial institutions to be extra innovative and consistently move forward (Phornlaphatrachakorn, 2019). The same goes for the Zakat Management Organization (ZMO) which is part of financial institutions. Knowing that technological advances are accelerating quickly, $\mathrm{ZMO}$ requires competent human resources in the field of zakat practice. In fact, there are not many intellectuals who are committed in this field and loyal to the zakat institutions. This lack of interest from the intellectuals gives impact on zakat institutions to move in slower progress.

The corporation category comes in third rank This is probably because their main focus is on company profit, and the existence of zakat organizations in their company is only for a facility for the employees to pay their zakat funds. Therefore, their value of productivity level is at 1,013 with an efficiency value $(\mathrm{EFFCH})$ of 0.885 and a technology innovation value $(\mathrm{TECH})$ only at 1,113. Thus, zakat institutions included to the corporation category should further improve EFFCH and TECH in order to increase their productivity. The productivity of a ZMO can be considered as 'growing' if ZMO can adapt well to the era development or innovate through electronic media or technology, because with the help of technology the corporate will have more efficiency in production (Jajri, Idris \& Ismail, 2007). To increase efficiency value, it requires knowledge of management, economics, politics and demography (Idris, A. Seng, 2011). Then, to improve EFFCH and TECH, several factors are needed, which include proper and adequate human resources, operational, and trainings. These three factors are closely related to the ups and downs of collecting process of zakat and distribution by $\mathrm{ZMO}$, and when these processes change, they will affect the productivity level of ZMO. In this global economic era, the corporation should be in favour because it can maximize productivity by having this great chance of facing the global economy supported by production network and global industry (Yeung, 2016) which can be used in managing zakat.

If further analysis is carried out related to individual rank of institution, the first three ranks are spread into three groups. It can be seen that one of civil social organizations sits on the first rank, namely the Global Zakat institution. Why is that so? This happens because Global Zakat can balance and synergize technological innovation with efficiency management and is also able to do the process of collecting and distributing zakat in which these two components affect the calculations of the value of EFFCH and TECH. This is what makes the productivity of Global Zakat greater and is in third place compared to BAZNAS, a government type of institution and is ranked second. The cause is that productivity is not measured only from one component, but the collaboration between the EFFCH and TECH components. Because TFPCH is a calculation between the amount of TECH value multiplied by EFFCH value (Kamarudin, F., Hue, C.Z., Sufian, F., \& Anwar, 2017).

National Zakat Agency (BAZNAS), Baitul Maal Mu'amalat (BMM), Baitul Maal PLN Foundation (YBM PLN), Dompet Dhuafa Republika Zakat (DDR), Rumah Organization (RZ), Global Zakat Organization, Infaq Amil Zakat Institute and Shodaqoh (LAZISNU) and the Madani Welfare Foundation (YAKESMA) have the value of TFPCH above 1 . This value indicates a positive change in productivity of each zakat institution. It can be seen that the value of efficiency (EFFCH) is above 0.8 and the value of technological innovation (TECH) is above 1. The value of EFFCH and TECH shows a change in technological innovation and efficiency. These two points have an indirect positive impact on the productivity level of the zakat organization. This result is different from the research initiated by Nurasyiah et al. (2019), where the productivity value of TFPCH of DDR, RZ, etc. does not reach the index 1 before the year of 2016, so it can be concluded that ZMO managed by civil social organizations such as DDR, RZ, etc. has experienced significant technological changes, and then achieved productivity index above 1 during the period of 2016 - 2018.

This study conducted research on 14 zakat organizations in Indonesia to determine the productivity level of each zakat institution using the Malmquist Index Summary. ZMO whose result value are below 1 have decreased in productivity. This can be caused by lack of technological innovation in operational activities so that it indirectly reduces the efficiency of distribution and 
collection of zakat funds. However, 9 out of 14 existing ZMO already reach malmquist index value above 1 . This shows that most of ZMO in Indonesia has credibility as proper organization and to continue innovation to collect, manage and distribute zakat funds. The innovations made by each ZMO, either through technology or other innovation tools, are parts of important aspect to increase productivity of the ZMO. Because by implementing great innovation, $\mathrm{ZMO}$ is able to do the management of zakat funds that is existed in each ZMO, which resulted in organization productivity. As for the level of productivity as a whole from the classification in each ZMO group in Indonesia, namely government, civil social organizations, and corporations, an increase of productivity can be witnessed.

\section{CONCLUSION AND IMPLICATION}

The conclusions of the results of this study can be explained as follow:

- The overall productivity of ZMO in Indonesia from the ZMO group managed by the government, corporations and civil social organizations on average from 2016-2018 is 1.005. ZMO run by the government gains an average of 1.879 and ZMO managed by civil social organizations gains an average of 1.422. Meanwhile, ZMO which is managed by corporations gains an average value of 1.410. This level of productivity is seen through changes in technology that organizations have developed during the research period.

- Zakat Management Organization (ZMO) which is managed by the government, namely BAZNAS, ranked in number 1 for its level of productivity. ZMO managed by civil social organizations that consist of Global Zakat, AlAzhar, DDR, IZI, Mizan, RZ, DD, NU, and Yakesma is ranked in number 2 for its level of productivity. ZMO managed by corporations, namely YBM PLN, BMM, MTT, and BSM, is ranked in number 3 for its level of productivity.

The suggestion from this study for ZMO in Indonesia is to further increase institutional productivity through the EFFCH Change Index (EFFCH) by maximizing output and the Technology Change Index (TECH) by maximizing the use of technology and innovation in each ZMO, then study for the government is that BAZNAS, as the only zakat management organization run by the government, is expected to be more focusing on managing ZIS funds distributed from the community, because BAZNAS indirectly has become the main driving force or the regulator of other ZMO in the management of zakat funds. Meanwhile, a suggestion for the academics/researchers, it is expected to continue similar research with a research period of more than three years. Another suggestion is for the Zakat Management Organizations, it is hoped that ZMO will increase the productivity of the institution by optimizing innovations in the management and distribution of zakat.

\section{REFERENCES}

[1] Abbas, A. (2020). Does Zakat Signal The Firm Value? An Additional Inference of Mining and Manufacturing Zakatnomics. International Journal of Zakat, Vol. 5(1).

[2] Abdullah,. \& Sapiei, N. S. (2018). Do Religiosity, Gender And Educational Background Influence Zakat Compliance? The Case Of Malaysia. International Journal of Social Economics, Emerald Publishing Limited 0306-8293., Vol. 45 No. https://doi.org/OI 10.1108/IJSE-03-2017-0091

[3] Ahmad, \& M. (2014). The Efficiency of Zakat Collection and Distribution: Evidence from Two Stage Analysis. Journal of Economic Cooperation and Development, 35, 3, (2014), 133-170.

[4] Aji, R. H. S. (2020). Dampak Covid-19 pada Pendidikan di Indonesia: Sekolah, Keterampilan, dan Proses Pembelajaran. Salam: Jurnal Sosial \& Budaya Syar'i. Vol. 7 No. 5 (2020), Pp. 395-402,.

[5] Akpan, M. N. U., \& Akpan, S. S. (2019). Effect of Voluntary Merger and Acquisition on Efficiency and Productivity of Nigerian Firms: Evidence from Data Envelopment Analysis (DEA) and Malmquist Productivity Index (MPI). Finance and Banking Review, $13(1 \& 2)$, $1-21$.

[6] Avenzora, \& J. . M. (2008). Analisis Produktivitas dan Efisiensi Industri Tekstil di Indonesia Tahun 2002-2004. Universitas Indonesia.

[7] Bahri, A. (2016). Zakat Sebagai Instrumen Pembangunan Ekonomi Kesejahteraan Umat. Li Falah Jurnal Studi Ekonomi Dan Bisnis Islam. http://download.garuda.ristekdikti.go.id/a rticle.php?article $=525406 \& \mathrm{val}=10734 \& \mathrm{t}$ itle=ZAKATpercent20SEBAGAIpercent 
20INSTRUMENpercent20PEMBANGU NANpercent20EKONOMIpercent20KE SEJAHTERAANpercent20UMMAT.

[8] BAZNAS., P. K. S. (2019). OUTLOOK Zakat 2020. Center of Strategic Studies PUSKAS BAZNAS. SBN: 978-6025708-50-3.

[9] Beik, I. S. (2009). Analisis Peran Zakat Dalam Mengurangi Kemiskinan: Studi Kasus Dompet Dhuafa Republika. Zakat \& Empowering -. Jurnal Pemikiran Dan Gagasan, 2, 45-53.

[10] BPS. (2019). Presentase Penduduk Miskin Maret 2019. https://www.bps.go.id/pressrelease/2019/ 07/15/1629/persentase-pendudukmiskin-maret-2019-sebesar-9-41persen.html.

[11] Databoks. (2019). Indonesa, Negara dengan Penduduk Muslim Terbesar di Dunia.

[12] Databoks. (2020). Indonesia Peringkat 9 dengan Kasus Covid-19 Tertinggi Se Asia.

https://databoks.katadata.co.id/datapublis h/2020/09/28/indonesia-peringkat-9dengan-kasus-covid-19-tertinggi-di-asiasenin-289.

[13] Deoranto, E. al. (2016). Productivity and Profitability Analysis of Apple Cider Production using American Productivity Center Method on KSU Brosem. Industria: Jurnal Teknologi Dan Manajemen Agroindustri. 5(3): 114124(2016) ISSN: 2252-7877 (Print) ISSN: 2548-3582 (Online).

[14] Djaghballou, C.-E., Djaghballou, M., Larbani, M., \& Mohamad, A. (2018). Efficiency and productivity performance of zakat funds in Algeria. International Journal of Islamic and Middle Eastern Finance and Management, 11(3), 474494.

https://doi.org/https://doi.org/10.1108/IM EFM-07-2017-0185

[15] [Djuanda, G. dkk. (2006). Pelaporan Zakat Pengurang Pajak Penghasilan. PT.Raja Grafindo Persada.

[16] Enhassi, A. et. al. (2007). Reflective Practice Benchmarking Masonry Labour Productivity. International Journal of Productivity and Performance Management., Vol. 56 No. https://doi.org/doi : $10.1108 / 17410400710745342$
[17] Facts., R. (2020). Agama di Dunia.

[18] Fadilah, S., Lesatari, R., \& Rosdiana, Y. (2017). Organisasi Pengelola Zakat (OPZ) : Deskripsi Pengelolaan Zakat dari Aspek Lembaga Zakat. KAJIAN AKUNTANSI Universitas Islam Bandung, Vol.18 No.

[19] Huda, N., Anggraini, D., Ali, K. M., Mardoni, Y., \& Rini, N. (2014). Prioritas Solusi Permasalahan Pengelolaan Zakat Dengan Metode AHP (Studi di Banten dan Kalimantan Selatan). Al-Iqtishad: Journal of Islamic Economics, 6(2), 223238. https://doi.org/10.15408/ijies.v6i2.1232.

[20] Idris, A. Seng, T. L. (2011). Exploring The Motives And Determinants Of Innovation Performance Of Malaysian Offshore International Joint Ventures. Management Decision Emerald Group Publishing Limited 0025-1747 DOI 10.1108/00251741111183799., Vol. 49 No.

[21] Isa, C. R., Foong, S. Y., \& Sambasivan, M. (2005). The Roles of Market Competition and Advanced Manufacturing Technology in Predicting Management Accounting and Control Systems Change. Malaysia: Asia Pacific Management Review (2005) 10(6), 397-403.

[22] Jaelani, A. (2015). Manajemen Zakat di Indonesia dan Brunei Darussalam. In IAIN Syekh Nurjati Cirebon. CV. Pangger.

[23] Jajri, Idris \& Ismail, R. (2007). Techniccal Efficiency, Technological Change and Total Factor Productivity Growth in Malaysian Manufacturing Sectors. MPRA (Munich Personal Rapec Archieve). University of Malaya.

[24] Kamarudin, F., Hue, C.Z., Sufian, F., \& Anwar, N. A. M. (2017). Does productivity of Islamic banks endure progress or regress? Empirical evidence using data envelopment analysis based Malmquist Productivity Index. Emerald Publishing Limited 0828-8666., Vol. 33 No.

[25] Keuangan., K. (2017). Mendudukkan Ide Pengelolaan Zakat Oleh Pemerintah. https://www.kemenkeu.go.ig/publikasi/ar tikel-dan-opini/mendudukkan-idepengelolaan-zakat-oleh-pemerintah

[26] Khamis, N., Sulaiman, A., \& Mohezar, S. 
(2014). Achieving e-Business Excellence through Knowledge Management and Organizational Learning Capabilities: A Malaysian Perspective. International Journal of Economics and Management 8 (2): 343 - 364 (2014) IJEM

[27] Khaw, L. H. (2019). Firm Risk And Corporate Policies: From The Shariah Certification Perspective. International Journal Of Business And Society, Vol. 20 No.

[28] Lo, M., Ramayah, T., \& Min, H. W. (2009). Leadership styles and organizational commitment: a test on Malaysia manufacturing industry. African Journal of Marketing Management, Vol. 1(6).

[29] Madania, Citra., Muhammad, N. (2016). Pemahaman Maqashid Syariah (Akal) Terhadap Kinerja Lembaga Zakat Yatim Mandiri Surabaya. Jurnal Ekonomi Syariah Teori Dan Terapan, Vol. 3 No. 3 Maret 2016:187-202.

[30] Maullo, M.J., \& Calo, S.B. (1993). Policy Management: An Architecture and Approach. IEEE Explore Digital Library (IEEE XPlore). https://doi.org/DOI: 10.1109/IWSM.1993.315293

[31] Meilianna, N. R., \& Purba, Y. A. (2020). Dampak Pandemi Covid-19 Terhadap PHK dan Pendapatan Pekerja di Indonesia. Jurnal Kependudukan Indonesia : Edisi Khusus Demografi Dan COVID-19, Juli 2020, 43-48.

[32] Muhamad, R., Melewar, T. C., \& Alwi, S. F. S. (2011). Segmentation and brand positioning for Islamic financial services. Europan Journal of Marketing : Emerald Group Publishing Limited, Vol. 46 No.

[33] Nadhari, A. . (2013). Pengelolaan Zakat di Dunia Muslim. Economic: Jurnal Ekonomi Dan Hukum Islam, Vol. 3, No.

[34] Nasution, \& Muhammad, A. (2019). The Utilization of Zakah Productive towards Micro-Business Growth and Mustahik Welfare. Jurnal Ekonomi Pembangunan: Kajian Masalah Ekonomi Dan Pembangunan. https://doi.org/doi : 10.23917/jep.v20i1.6576.

[35] Nasution, D. A. D., Erlina, \& M. I. (2020). Dampak Pandemi Covid-19 Terhadap Perekonomian Indonesia. Jurnal Benefita (2) Juli 2020 (212-224).

[36] Negar, et, A. (2017). Malmquist Productivity Index In Ratio Data Envelopment
Analysis. Journal of Data Envelopment Analysis and Decision Science 2017 No. $1 \quad$ (2017) 7-13. https://doi.org/doi:10.5899/2017/dea00143.

[37] Nugraha, Q. (2018). Manajemen Strategis Pemerintahan.

[38] Nurasyiah, A., Adam, F., \& Pertiwi, R. S. (2019). Efficiency and Productivity of Zakat Institution in Malaysia and Indonesia: The Comparative Study. INTERNATIONAL CONFERENCE OF ZAKAT 2019 PROCEEDINGS.

[39] Nurprihatin, F. \& H. T. (2017). Pengukuran Produktivitas Menggunakan Fungsi Cobb-Douglals Berdasarkan Jam Kerja Efektif. Journal of Industrial Engineering and Management Systems., Vol. 10, N.

[40] Obi, O. F., \& Visser, R. (2020). Productivity measurement of New Zealand forest harvesting sector using the DEAMalmquist index. International Journal Of Forest Engineering, 10. https://doi.org/https://doi.org/10.1080/14 942119.2020.1770566

[41] Parisi, S. A. (2017). Tingkat Efisiensi dan Produktivitas Lembaga Zakat di Indonesia. https://doi.org/CXCF 63-72. https://doi.org/10.15408/ess.v7i1.3687

[42] Parker, L. D. (1984). Control in Organizational Life: The Contribution of Mary Parker Follett. Academy of Management Review. 984, Vol. 9. Na. https://doi.org/https://doi.org/10.5465/am r.1984.4277620

[43] Pathak, H. P. (2019). Malmquist Productivity Index Approach in Assessing Performance of Commercial Banks: Evidence from Nepal. NRB Economic Review, 31(2), 25-55.

[44] Phornlaphatrachakorn, K. (2019). Effect of Transformational Leadership, Organizational Learning and Technological Innovation on Strategic Management Accounting in Thailand's Financial Institutions. Asian Journal and Business Accounting 12(1), 2019. https://doi.org/doi :

https://doi.org/10.22452/ajba.vol12no1.6

[45] Piliyanti, I., \& Meilani, S. E. R. (2020). Benchmarking Lembaga Zakat Berbasis Kampus: Kajian Atas Efisiensi Lembaga Menggunakan Data Envelopment 
Analysis. Jurnal Perspektif Ekonomi Darussalam, 6(1), 15-35.

[46] Raphael, G. (2013). A DEA based malmquist productivity index approach in assessing performance of commercial banks: Evidence from Tanzania. European Journal of Business and Management, Vol. 5, No.

[47] Religion, M. of. (2013). Panduan Zakat Praktis. In Jakarta:Direktorat Pemberdayagunaan Zakat Kementerian Agama Republik.

[48] Rustyani, S., \& Rosyidi, S. (2019). Measurement of Efficiency And Productivity of Amil Zakat Institutions in Indonesia By Using Data Envelopment Analysis Methods And Malmquist Productivity Index. Jurnal Ekonomi Syariah Teori Dan Terapan, 6(2), 270287.

[49] Rusydiana, A. S. (2018). Perubahan Teknologi Dan Efisiensi Pada Organisasi. Liquidity, 7(2), 124-136.

[50] Sarrens, G., \& Christopher, J. (2010). The association between corporate governance guidelines and risk management and internal control practices Evidence from a comparative study. Managerial Auditing Journal Vol. 25 No. 4, 2010 Pp. 288-308. Emerald Group Publishing. Limited 0268-6902. https://doi.org/DOI 10.1108/02686901011034144.

[51] Sartawi, A. (2020). Shariah Disclosure and the Performance of Islamic Financial Institutions. Asian Journal Business and Accounting $\quad 2020$. https://doi.org/doi : https://doi.org/10.22452/ajba.vol13no1.5

[52] Tzeremes, N. G. (2020). Robust malmquist productivity measurement: Evidence from Spanish hotel industry during the Great Recession. International Journal of Productivity and Performance Management, Ahead-of-Print(Ahead-ofPrint). https://doi.org/https://doi.org/10.1108/IJ PPM-01-2019-0037

[53] Wahab, N. Abd., \& Rahman, A. R. A. (2012). Productivity growth of zakat institutions in Malaysia: An application of data envelopment analysis. Studies in Economics and Finance, 29(3), 197-210. https://doi.org/https://doi.org/10.1108/10
867371211246876

[54] Wahab, N. Abd., \& Rahman, A. R. A. (2013). Determinants of Efficiency of Zakat Istitutins in Malaysia : A-Non Parametric Approuch. Asian Journal of Business and Accounting 6(2), 2013. ISSN 1985-4064.

[55] Wahbah, M. S. dkk. (1984). Dirasah Muqaranah fi Zakat al-Maal. Tihama.

[56] Yacoeb, M. (2013). KONSEP MANAJEMEN DALAM PERSPEKTIF ALQUR'AN: Suatu Analisis dalam Bidang Administrasi Pendidikan. Jurnal Ilmiah DIDAKTIKA Agustus 2013 VOL. XIV NO. 1, 74-89.

[57] Yaumidin, U. K. (2007). Efficiency in Islamic banking, A non-parametric approach,. Buletin Ekonomi Moneter Dan Perbankan, April 2007.

[58] Yeung, W. C. (2016). Strategic Coupling East Asian industrial Transformation In The New Global Economy. New York: Cornell University Press. ISBN 978-15017-0256-3.

[59] Yildirim, I. (2015). Financial efficiency analysis in Islamic banks: Turkey and Malaysia models. Journal of Economics, Finance and Accounting, Vol. 2, Is. 